\title{
Firm-Size Distribution and Price-Cost Margins in Dutch Manufacturing
}

\begin{abstract}
Industrial economists surmise a relation between the size distribution of firms and performance. Usually, attention is focused on the high end of the size distribution. The widely used four-firm seller concentration ratio, $\mathrm{C} 4$, ignores what happens at the low end of the size distribution. We investigate to what extent the level and the growth of small business presence influence price-cost margins in Dutch manufacturing. We use a large data set of 66 industries for a thirteen year period. This allows the investigation of both small business influences within a framework in which that of many other market structure variables is also studied. Evidence is shown that price-cost margins are influenced by large firm dominance, growth in small business presence, capital intensity, business cycle, international trade and buyer concentration.
\end{abstract}

\section{Introduction}

In the industrial organisation literature it is wellestablished that the market power to raise price above cost increases with increasing seller concentration. ${ }^{1}$ Seller concentration refers to the number and size distribution of firms. Concentration changes through mergers, entry and exit, and by the rise or fall of incumbents induced by the intensity of competition. So, concentration is often

Final version accepted on July 15, 1992

Department of Fundamental Research

Research Institute for Small and Medium-Sized Business (EIM)

P.O. Box 7001

2701 AA Zoetermeer

The Netherlands

Department of Fundamental Research

Research Institute for Small and Medium-Sized Business (EIM)

P.O. Box 7001

2701 AA Zoetermeer

and Centre for Advanced Small Business Economics

(CASBEC) of Erasmus University Rotterdam (EUR)

P. O. Box 1738

3000 DR Rotterdam, The Netherlands used as a measure of the competitive forces within an industry. ${ }^{2}$ However, measures of seller concentration may remain unchanged when the number and size distribution of firms changes.

Most concentration measures use data of only a small number of firms. The widely used four-firm concentration ratio is equal to the share accounted for by the largest four firms in an industry. The main disadvantage of the four-firm concentration ratio is that it represents only a small part of the size distribution of firms. Whether a high four-firm concentration ratio is due to only one or two very large firms, or whether the share of all other firms is mainly in hands of small ones, is not evident from the level of the four-firm concentration ratio. Therefore, additional aspects of the firm-size distribution next to the four-firm concentration ratio should be taken into account.

In this paper, we want to investigate to what extent Dutch manufacturing price-cost margins are influenced by (1) the presence of one or two large firms which dominate the other firms within an industry (large firm dominance) and (2) the share of small business (small business presence), next to other market structure variables. Large firm dominance and small business presence are used as measures of the firm-size distribution next to the four-firm seller concentration ratio.

Recent textbooks on industrial organisation have paid little attention to the presence of small business. Only a few scattered sentences are devoted to the effects of small business presence: 'Competition from smaller firms limits the ability of the largest firms to exercise market power' (Martin, 1988, p. 184) and 'In general, oligopoly price structure breakdowns are more likely, the higher the proportion of industry capacity in the hands of competitive fringe producers...' (Scherer and Ross, 1990, p. 279). In our search for previous empirical studies on the influences of small business presence on price-cost margins we

Small Business Economics 5: 173-186, 1993.

(C) 1993 Kluwer Academic Publishers. Printed in the Netherlands. 
did not find any explicit empirical contribution. ${ }^{3}$ So we must conclude that influences of small business share have never been explicitly empirically investigated. Probably, this is the case because it is mostly argued that the division of the firms into the largest four and all others gives sufficient information about the distribution of the market power. Moreover, numerous studies have found concentration ratios and other statistics of firm-size distribution to be highly correlated. ${ }^{4}$ For this reason it is often supposed that empirical investigations will yield similar results regardless of the concentration measure chosen. However, Kwoka (1981) shows that alternative concentration ratios which are highly correlated do not necessarily lead to similar results in studies relating concentration ratios to performance.

So it will be useful to focus on a more appropriate measurement of the size distribution of firms. First, a further division of the remainingfirm share into that of small and larger (mediumsized) firms is of importance when investigating the influence of market structure on industry's price-cost margins. The power of the largest firms might be diminished by the presence of many small firms. Second, a closer look at the market share distribution among the four largest firms is required because it is not obvious that the largest four firms are of equal importance. And why should exactly the largest four firms reflect the ability of an industry to raise price above cost? The results of Kwoka (1979), in which market share data of 314 U.S. manufacturing industries for 1972 are used, suggest that this ability depends on the sizes of the top two firms. A third large firm appears to have a negative effect on price-cost margins, suggesting that this firm is a rival rather than a partner in the collusion.

In this paper we will consider influences of small business presence and large firm dominance on price-cost margins by introducing these variables into a model which includes other market structure variables like the four-firm seller concentration ratio, buyer concentration, capital intensity, business cycle and international trade measures. In the next section we describe the data used. In section III the influences of several market structure variables on price-cost margins are investigated. In section IV further attention is paid to the effects of small business presence. The conclusions are presented in the final section.

\section{Data}

We use the Dutch manufacturing data set DUMA, ${ }^{5}$ covering the period 1974-1986 and consisting of 66 three-digit $^{6}$ industries. This data set is mainly based on the 'Production Statistics Manufacturing Industry' published by the Netherlands Central Bureau of Statistics. Unfortunately, firms employing less than 10 people are not included. The coverage ratio in terms of employment (1986) of the manufacturing sector with firms employing 10 or more employees is $87 \%$ and that of the total manufacturing sector is $81 \%$. Not all two-digit industries are covered. The notoriously difficult petroleum industry and miscellaneous (n.e.c., other) manufacturing industries are left out and data for the instrument engineering industry became available first in 1980 .

We collected additional information to investigate the effect of large firm dominance on Dutch manufacturing price-cost margins. The starting point was a list of the 25 largest industrial enterprises in the Netherlands, measured in employment figures (1985), published in De Smidt and Wever (1987, p. 161). Each of these enterprises was classified in a three-digit industry by the combination of several statistics. ${ }^{7}$ Some enterprises were split up according to economic activity and hence classified in more than one three-digit industry. Also, some enterprises were assigned to three-digit industries which are not covered by our data set. Classification of the enterprises supplied thirteen three-digit industries which are dominated by one or two large firms. This procedure yields that an industry is defined as a dominated industry when one firm accounts for more than $40 \%$ or two firms account for more than $50 \%$ in the number of employees.

Additional data were also gathered to calculate the share of small firms. The numbers of full-time employees and firms ${ }^{8}$ per three-digit industry for the period 1974-1986 were constructed from the compilation of the 'Statistics of Man-years and Gross Wages'. The share of small business is defined as the share accounted for by firms with 10 to 50 employees. We were able to measure the 
presence of small firms - given the available data - by the number of employees and by the number of firms accounted for by firms employing 10 to 50 employees. Measurement in employment has one important drawback: if small firms are more labour-intensive, employment measures will overstate their relative importance. Therefore, we prefer measuring the small business presence by the number of firms. ${ }^{9}$

Table I lists the four-firm seller concentration ratio $(C 4)$, small business presence $(S B P)$ and price-cost margin $(P C M)$ in 1986 of the 66 threedigit industries of our data set. As shown in Table I, the measures of the lower and the upper tail of the firm-size distribution, $S B P$ and $C 4$ respectively, vary considerably across the industries. Office machinery (35.8) is the most concentrated industry: $98 \%$ of the employment is concentrated in the largest four firms. The lowest level of concentration is found in the manufacture of furniture (25.7) where only $5 \%$ is employed by the largest four firms. The share of small firms in an industry measured in firms, $S B P$, varies from 0.07 (chemical detergents (29.8)) to 0.88 (bread, rusks, cakes, biscuits (20.8), other wooden articles (25.5), furniture (25.7), forges, surface treatment (34.9)). ${ }^{10}$ Clearly, as is shown by the high concentration of small firms and low concentration in the largest four firms $(S B P \geqslant 0.80$ and $C 4 \leqslant 0.10)$, the manufacture of bread etc. (20.8), furniture (25.7), printing (27.1), other metal construction (34.4), and forges etc. (34.9) are small-scaled industries.

The variation in price-cost margins appears to

TABLE I

Four-firm seller concentration ratio (C4), small business presence $(S B P)$ and price-cost margin $(P C M)$ per three-digit industry (1986)

\begin{tabular}{|c|c|c|c|c|}
\hline Industry & $\operatorname{code}^{\mathbf{a}}$ & $C 4$ & $S B P$ & $P C M$ \\
\hline slaughtering, meat processing & 20.1 & 0.22 & 0.68 & 0.06 \\
\hline flour mills, groats & 20.4 & 0.60 & 0.50 & 0.12 \\
\hline margarine, oils and fats & 20.6 & 0.59 & 0.47 & 0.11 \\
\hline canning fruits and vegetables & 20.7 & 0.19 & 0.51 & 0.17 \\
\hline bread, rusks, cakes, biscuits & 20.8 & 0.10 & 0.88 & 0.19 \\
\hline cocoa, chocolate & 20.9 & 0.39 & 0.49 & 0.12 \\
\hline animal stock feeds & 21.2 & 0.30 & 0.69 & 0.08 \\
\hline other food products & 21.3 & 0.37 & 0.61 & 0.14 \\
\hline non-alcoholic beverages & 21.6 & 0.47 & 0.25 & 0.35 \\
\hline wool and cotton & 22.12 & 0.46 & 0.47 & 0.14 \\
\hline knitting and hosiery & 22.3 & 0.29 & 0.64 & 0.18 \\
\hline carpets and rugs & 22.5 & 0.34 & 0.25 & 0.14 \\
\hline ready-made clothing & 23.12 & 0.18 & 0.71 & 0.11 \\
\hline leather & 24.1 & 0.54 & 0.76 & 0.12 \\
\hline leatherware & 24.2 & 0.23 & 0.84 & 0.15 \\
\hline footwear & 24.3 & 0.19 & 0.74 & 0.12 \\
\hline carpeting, parqueting & 25.3 & 0.15 & 0.82 & 0.15 \\
\hline wooden containers & 25.4 & 0.23 & 0.75 & 0.17 \\
\hline other wooden articles & 25.5 & 0.33 & 0.88 & 0.19 \\
\hline furniture (excl. metal) & 25.7 & 0.05 & 0.88 & 0.18 \\
\hline paper and cardboard & 26.1 & 0.40 & 0.10 & 0.30 \\
\hline paperware & 26.2 & 0.23 & 0.43 & 0.18 \\
\hline corrugated cardboard & 26.3 & 0.23 & 0.53 & 0.19 \\
\hline printing & 27.1 & 0.08 & 0.83 & 0.21 \\
\hline publishing & 27.2 & 0.21 & 0.60 & 0.24 \\
\hline book binding & 27.3 & 0.18 & 0.78 & 0.24 \\
\hline fertilizers & 29.1 & 0.93 & 0.25 & 0.14 \\
\hline
\end{tabular}


Table I (continued)

\begin{tabular}{|c|c|c|c|c|}
\hline Industry & $\operatorname{code}^{a}$ & C4 & $S B P$ & PCM \\
\hline plastics & 29.2 & 0.66 & 0.29 & 0.21 \\
\hline dye-stuffs and pigments & 29.3 & 0.72 & 0.47 & 0.28 \\
\hline other basic chemicals, fibres & $29.4,30$ & 0.64 & 0.28 & 0.25 \\
\hline paint, lacquer, varnish & 29.5 & 0.59 & 0.63 & 0.22 \\
\hline pharmaceutical & 29.6 & 0.60 & 0.51 & 0.29 \\
\hline soap, perfumes, cosmetics & 29.7 & 0.35 & 0.35 & 0.23 \\
\hline chemical detergents & 29.8 & 0.72 & 0.07 & 0.19 \\
\hline other chemical products & 29.9 & 0.40 & 0.50 & 0.24 \\
\hline rubber-processing & 31.1 & 0.65 & 0.53 & 0.20 \\
\hline plastic-processing & 31.3 & 0.19 & 0.67 & 0.23 \\
\hline bricks, tiles, and earthenware & 32.12 & 0.42 & 0.81 & 0.34 \\
\hline sand-lime bricks & 32.3 & 0.50 & 0.38 & 0.40 \\
\hline concrete and cement products & 32.5 & 0.17 & 0.71 & 0.26 \\
\hline iron, steel and non-ferrous metal & 33.124 & 0.76 & 0.17 & 0.23 \\
\hline wire-drawing and cold-rolling & 33.3 & 0.38 & 0.52 & 0.17 \\
\hline foundries & 34.0 & 0.36 & 0.63 & 0.20 \\
\hline iron works & 34.1 & 0.45 & 0.70 & 0.25 \\
\hline screws and springs & 34.2 & 0.48 & 0.74 & 0.21 \\
\hline tanks, reservoirs, pipelines & 34.3 & 0.17 & 0.66 & 0.14 \\
\hline other metal construction & 34.4 & 0.10 & 0.81 & 0.14 \\
\hline metal furniture & 34.5 & 0.29 & 0.64 & 0.23 \\
\hline metal-packing, other metal products & 34.68 & 0.30 & 0.72 & 0.19 \\
\hline heating and cooking apparatus & 34.7 & 0.49 & 0.57 & 0.18 \\
\hline forges, surface treatment & 34.9 & 0.10 & 0.88 & 0.34 \\
\hline agricultural machinery & 35.1 & 0.36 & 0.80 & 0.17 \\
\hline metal-working machinery & 35.2 & 0.16 & 0.76 & 0.23 \\
\hline machinery for food processing & 35.3 & 0.20 & 0.61 & 0.18 \\
\hline transport equipment for construction & 35.4 & 0.13 & 0.70 & 0.19 \\
\hline bearings and other driving gear & 35.5 & 0.46 & 0.73 & 0.19 \\
\hline machinery for industries n.e.s. & 35.6 & 0.42 & 0.67 & 0.26 \\
\hline steamboilers, engines, turbines & 35.7 & 0.40 & 0.63 & 0.16 \\
\hline office machinery & 35.8 & 0.98 & 0.62 & 0.11 \\
\hline other machinery and apparatus & 35.9 & 0.09 & 0.73 & 0.19 \\
\hline electrotechnical & 36 & 0.67 & 0.62 & 0.24 \\
\hline automobiles, car parts, aircraft & 37.137 & 0.86 & 0.51 & 0.08 \\
\hline coach work and trailers & 37.2 & 0.17 & 0.75 & 0.16 \\
\hline shipbuilding & 37.4 & 0.30 & 0.70 & 0.08 \\
\hline bicycles, motorcycles & 37.6 & 0.62 & 0.75 & 0.11 \\
\hline other transport equipment & 37.9 & 0.36 & 0.79 & 0.18 \\
\hline
\end{tabular}

The four-firm seller concentration ratio, C4, is defined as the employment share accounted for by the largest four firms. Small business presence, $S B P$, is defined as the share in the number of firms accounted for by small firms. The price-cost margin is defined as the ratio between output minus labour and material costs and output.

a SBI-code: the Dutch industrial classification of firms developed by the Netherlands Central Bureau of Statistics.

be somewhat less. Price-cost margins are lowest, i.e. 0.06 , in the slaughtering and meat processing (20.1) and largest, i.e. 0.40 , in the sand-lime bricks industry (32.3).

When looking for relations between the two firm-size distribution measures, $C 4$ and $S B P$, on the one hand and price-cost margins on the other hand we notice the following. We see that highly concentrated industries $(C 4 \geqslant 0.80)$ in which more than a half of the firms have 10 to 50 employees (office machinery (35.8) and automobiles, car parts, aircraft (37.137)) do have a 
relatively low price-cost margin but that for the highly concentrated fertilizer industry (29.1) the price-cost margin is somewhat higher. In the latter industry only a fourth of the firms employ 10 to 50 employees. These figures suggest that the market power to set prices above cost represented by the four-firm concentration ratio is diminished by a high small business presence.

However, moderately concentrated industries, having a concentration ratio between 0.60 and 0.80 , give another image. Among this group of ten industries we focus on the two industries with the highest level of price-cost margin: manufacture of dye-stuffs and pigments (29.3) and the pharmaceutical industry (29.6). For these industries $47 \%$ and $51 \%$, respectively, of the firms employ 10 to 50 employees. Thus, among the group of moderately concentrated industries high levels of pricecost margins go along with high levels of small business presence contradicting the above-mentioned finding for the highly concentrated industries.

So, the interaction between the influences of the four-firm seller concentration ratio and small business presence on price-cost margins is not straightforward. Below we will investigate these relationships more systematically by means of a model explaining price-cost margins.

\section{Explanation of Dutch manufacturing price- cost margins}

In this section we will consider a model to explain differences in price-cost margins of Dutch manufacturing industries. The selection of some market structure variables draws upon the recent empirical study of Prince and Thurik (1992). ${ }^{11}$ Their aim was to investigate the relationship between seller concentration and Dutch manufacturing pricecost margins and its development over time, i.e. whether price-cost margins are more procyclical in more concentrated than in less concentrated industries. In our present study the emphasis is on investigating the influences of the firm-size distribution variables like large firm dominance and small business share next to that of the four-firm seller concentration ratio. The following hypotheses will be tested:

\section{Seller concentration}

The ability of an industry to raise price above cost increases with increasing four-firm seller concentration ratio, $C 4$, i.e. the share of total employment accounted for by the four largest firms within an industry. ${ }^{12}$

\section{Capital intensity}

The higher the amount of capital involved within an industry the more difficult it is to enter. When the threat of potential entry is low it allows incumbents to keep prices above competitive levels. Thus, capital-intensive industries are expected to have higher price-cost margins than labour-intensive industries. ${ }^{13}$ In the present study the total amount of fixed-capital formation in the preceding 10 years is assumed to approximate the level of capital. ${ }^{14}$ So capital intensity, $K$, is measured by the ratio of the value of the cumulative investments in the preceding 10 years (deflated) and output (deflated).

Furthermore, $K$ controls for differences in capital costs which are not deducted in the computation of the price-cost margin and which undoubtedly play a role when prices are set. Then, the capital costs must be allowed for by including $K$ as an explanatory variable.

\section{Business cycle}

Domowitz, Hubbard and Petersen (1986) and Prince and Thurik (1992) presented extensive investigations on the cyclical behaviour of pricecost margins in U.S. and Dutch manufacturing industries, respectively. Following these studies influences of the business cycle are measured both at the supply and the demand side by the degree of capacity utilization, ${ }^{15} \mathrm{CU}$, and the relative change in sales (deflated), $R S$, respectively. Both variables measure fluctuations in the demand level, while the former is also influenced by supply effects such as choice of technology, efficiency, etc.

In a business cycle downturn when demand is slack industries will lower their prices to compensate the loss of sales: lower prices will attract more buyers. In a booming stage industries will set higher prices in order to benefit from the growing spending of their buyers. However, the extent to 
which prices can be raised is limited because too high prices will result in sales losses. So, we expect price-cost margins to be higher in business cycle upswings than in downturns.

Cubbin (1988, p. 21), however, points out that a low degree of capacity utilization can be the result of a deliberate creation of entry barriers by incumbents by holding excess capacity. In this case we would expect a negative relation between capacity utilization and industry's price-cost margin.

\section{International trade}

In a small open economy like the Netherlands influences of exports and competing imports are expected to affect manufacturing price-cost margins. Competing imports, $\mathrm{CI}$, are expected to have a negative influence on price-cost margins because they do increase the degree of competition within an industry.

Industrial economists give theoretical explanations for positive as well as negative influences of exports on price-cost margins. ${ }^{16}$ We will not discuss them all, we just mention two examples here. On the one hand, export activities might be needed for survival when the domestic market is too small to dispose of all products. On the other, it is argued that a firm will only operate on foreign markets when their exporting activities are rewarded by a risk premium. Empirical results of the influences of exports are contradictory too: positive as well as negative effects of exports on price-cost margins are found. See, for example, Pagoulatos and Sorensen (1976) in which inconsistent effects of exporting activities are found in several EC-countries.

\section{Buyer concentration}

The influences of the four-firm seller concentration and the share of exports are supposed to be dependent on concentration of the buyers. Countervailing power of the buyers is assumed to diminish the market power to set prices above costs. See also Brooks (1973), Lustgarten (1975), Collins and Preston (1969) and Schumacher (1991). Based on the assumption that a low buyer concentration on the domestic market also holds for the foreign market we expect the influence of exports on price-cost margins to depend upon buyer concentration. ${ }^{17}$

In this study we use an inverse measure of the degree in which buyers are concentrated. The share of household consumption, $P C$, is defined as the ratio of consumption expenditures of households and final output minus exports. The lower the share of household consumption the lower the number of buyers, and thus the higher buyer concentration is. We include the multiplicative terms, C4PC and EXPC, to measure the cross effects between seller and buyer concentration and between exports and buyer concentration, respectively. The expected sign of $C 4 P C$ is positive, whereas that of $E X P C$ is negative.

\section{Large firm dominance}

Possibly the supposed positive relationship between price-cost margins and seller concentration is due largely to the presence of one or two dominant firms within an industry. See Kwoka (1979). Furthermore, in the Netherlands there are relatively many large international manufacturing firms (for example, Unilever, Philips, Hoogovens, T\&D-Verblifa, AKZO, VMF-Stork) which are expected to play a dominant role within a threedigit industry. Thirteen industries of our data set are found to be dominated by one or two large firms. The dummy-variable DDom equals one when the industry is dominated and equals zero otherwise and is expected to be positively related to the industry's price-cost margins.

\section{Small business presence}

We expect that a high share of small business goes together with a low level of price-cost margins. A high small business presence, implying that there are many small firms, leads to a higher level of competition than when fewer, but larger firms are present.

Next to this measure we introduce the relative change in small business share. The growth in the share of small business can be seen as an indicator of the growth in the level of competition. If the number of small firms increases the degree of competition will rise. Actually, the change in small business share is partly the result of the height of the entry barriers. In the presence of low entry 
barriers there will be considerable entry of small firms resulting in more competition and consequently in low price-cost margins. The relative change in small business presence, $R S B P$, is expected to have a negative impact on price-cost margins.

Regression ${ }^{18}$ yields the following results (tvalues are in parentheses):

$$
\begin{aligned}
P C M_{i t}= & 0.063-0.056 C 4_{i t}+0.020 K_{i t}+ \\
& (4.1) \quad(-2.3) \quad(2.6) \\
+ & 0.109 C U_{i t}+0.049 R S_{i t}+ \\
& (12.1) \quad(6.6) \\
+ & 0.083 E X_{i t}-0.014 C I_{i t}+ \\
& (3.8) \quad(-5.6) \\
+ & 0.107 C 4 P C_{i t}-0.123 E X P C_{i t}+ \\
& (3.1) \quad(-3.8) \\
+ & 0.021 D D o m_{i t}+0.016 S B P_{i t}- \\
& (2.5) \quad(1.2) \\
- & 0.007 R S B P_{i t} \\
& (-2.2) \quad \bar{R}^{2}=0.631
\end{aligned}
$$

number of observations: 792

where

PCM: price-cost margin, i.e. (outputlabour cost-material cost)/output

C4: four-firm concentration ratio measured in employment

$K: \quad$ capital intensity

$C U: \quad$ capacity utilization

$R S: \quad$ relative change in sales

$E X$ : export share, i.e. foreign sales divided by total sales

$C I$ : competing imports divided by domestic sales

$P C$ : share of household consumption (inverse of buyer concentration)

DDom: dummy-variable for dominated industries (equals one when an industry is dominated, equals zero otherwise)

$S B P: \quad$ share of small business measured in firms

$R S B P$, relative change in the share of small business

index of industry

year of observation
The effect of each explanatory variable appearing in equation (1) on price-cost margins will be discussed below.

On first consideration the influence of the fourfirm seller concentration ratio, $C 4$, on price-cost margins is negative and significantly ${ }^{19}$ so. However, the effect of seller concentration on pricecost margins is also determined by the coefficient of the multiplicative term C4PC. The effect of seller concentration on price-cost margins is $\partial P C M / \partial C 4=-0.056+0.107 P C$. For an industry with an average level of $P C$ among the 66 industries $\left(P C^{\mathrm{a}}=0.546\right) \partial P C M / \partial C 4=0.002$, with corresponding $t$-value 0.1 . This indicates that the influence of seller concentration on price-cost margins is positive but statistically insignificant.

The estimated coefficient of the measure of capital intensity $K$ is positive, implying that more capital-intensive industries have higher price-cost margins than industries in which the capital intensity is lower.

Both business cycle measures, $C U$ and $R S$, have a positive impact on price-cost margins. A higher utilization of the capacity leads to higher price-cost margins than when a considerable part of capacity is unused. This result implies that the higher excess capacity the lower price-cost margins and thus rejects the view that excess capacity is held to create artificial entry barriers. Furthermore, in a business cycle upswing represented by a positive relative change in sales, price-cost margins are higher than in a downturn when demand is declining.

The influence of exports, $E X$, depends on the coefficients of the variable $E X$ and the multiplicative variable $E X P C$ : $\partial P C M / \partial E X=0.083-$ $0.123 P C$. In the case of a low number of buyers $(P C=0)$ the effect of exports on price-cost margins is positive. On the other hand when there is a very large number of small buyers $(P C=1)$ exports influence price-cost margins negatively.

When an industry faces competing imports, $C I$, domestic firms have to compete with foreign sellers too. As expected this lowers the industry's price-cost margins.

So far, we have considered the more traditional market structure variables. We notice that the empirical results are in agreement with our expectations and also with earlier results obtained in Prince and Thurik (1992). Now we will discuss 
the influences of large firm dominance and small business presence.

The effect of the dummy-variable for dominated industries, DDom, is a positive one. Industries which are dominated by one or two large international firms have the ability to set prices above competitive levels. We already noticed that the four-firm seller concentration ratio does not influence the level of price-cost margins. This means that support is found for the result of Kwoka (1979): market power to set prices above cost is reflected by the sizes of the top two rather than the top four firms.

The measure of the firm-size distribution on the other end of the distribution, $S B P$, appears to have an unexpected positive sign, suggesting that a high small business presence goes along with higher price-cost margins than when only a few small firms are present. However, this effect of small business presence is not significant.

The coefficient of the relative change in small business presence, $R S B P$, is negative and significantly so. If entry barriers are low and the conditions to enter are prosperous, incumbents will be joined by new firms. An increase in the number of firms will intensify competition and lower the industry's price-cost margins.

\section{Further tests on effects of small business presence}

The above results show that the small business share does not have a significant effect on pricecost margins. Ignoring the effects of small business presence in studies focusing on the explanation of the industry's price-cost margins seems no major drawback. However, this is a rather strong conclusion based on the exercise shown in section III only. We shall further explore the effects of small business presence in this section.

First, we shall divide the whole sample of 66 industries into two subsamples according to the level of small business share. This enables to investigate whether the explanatory variables have disparate impacts on price-cost margins for the industries classified in the two subsamples. Also, the hypothesis 'competition from smaller firms limits the ability of the largest firms to exercise market power' (Martin, 1988, p. 184) can be tested. Support for this hypothesis is found when the influence of seller concentration is significantly larger for the subsample including industries with relatively less small firms than for the subsample of industries in which a relatively large number of small firms is present.

Second, we shall consider whether there is a discontinuity in the influence of the small business share on price-cost margins. This approach implies a test of a less strong hypothesis than the first one. In the second approach only the effect of small business share, and not that of all other explanatory variables, is expected to differ between the subsamples with a low and a high small business presence. Below we will discuss both methods in more detail.

\section{Sample division}

We investigate whether the influences of all explanatory variables appearing in equation (1) differ between industries with a low and a high average small business share by means of sample division. The sample of 66 industries is divided into two subsamples: one containing industries with an average share of small business lower than a certain level $S^{*}$ and one containing the remaining part of the industries. We had no a priori preference for the value of $S^{*}$ so we ran separate regressions for the subsamples defined by some values of $S^{*}$. Given our data set we chose $S^{*}=$ $0.50,0.55,0.60,0.65$, and 0.70 .

For each value of $S^{*}$ Chow-tests ${ }^{20}$ of testing the pooled model against the sample division are in favour of the pooled model. So the estimation results of the two subsamples do not differ significantly from each other. However, the different sample divisions all show individual coefficients which do differ significantly. See Table II.

For each pair of subsamples defined by $S^{*}=$ $0.50,0.55$ and 0.70 only the coefficients of the capacity utilization differ significantly, but for those defined by $S^{*}=0.60$ and 0.65 three coefficients are significantly different from each other. The variables of which the estimated coefficients differ significantly are the capital intensity, the degree of capacity utilization, and the level of competing imports. The coefficient of capital intensity is significantly higher for industries with a relatively high small business share than for those with a relatively low small business share. For the 
TABLE II

Coefficients that differ significantly between the two subsamples defined by $S^{*}$

$S^{*} \quad$ variable sample with $S B P<S^{*}$ sample with $S B P \geqslant S^{*}$

\begin{tabular}{llrrrrr}
\hline 0.50 & $C U$ & 0.128 & $(7.2)$ & 0.075 & $(6.5)$ \\
0.55 & $C U$ & 0.144 & $(8.9)$ & 0.093 & $(8.2)$ \\
0.60 & $K$ & 0.019 & $(2.3)$ & 0.056 & $(3.8)$ \\
& $C U$ & 0.157 & $(11.0)$ & 0.076 & $(6.7)$ \\
& $C I$ & $-0.023(-5.8)$ & -0.008 & $(-2.6)$ \\
0.65 & $K$ & 0.019 & $(2.3)$ & 0.059 & $(3.9)$ \\
& $C U$ & 0.156 & $(11.3)$ & 0.073 & $(6.2)$ \\
& $C I$ & $-0.023(-6.1)$ & -0.008 & $(-2.1)$ \\
0.70 & $C U$ & $0.128(10.7)$ & 0.090 & $(6.5)$ \\
\hline
\end{tabular}

coefficient of the capacity utilization the opposite holds. The former result is somewhat surprising. Apparently, it is more difficult to entry an industry with already a high level of small business than one in which there are less small firms. The latter result means that industries with a relatively low small business share, implying a high presence of larger firms, appear to move their prices in a better accord to fluctuations in the utilization of capacity. Probably, large firms do better plan the utilization of capacity and the corresponding price-setting. The negative coefficient of competing imports is lower for industries with a relatively low small business share than for those with a relatively high small business presence. As expected competition from abroad does affect large firms rather than small firms.

Furthermore, the estimation results show that the effect of seller concentration on price-cost margins is larger for industries with a small business share below $S^{*}$ than for industries with a small business share above $S^{*}$ for all values of $S^{*}$, however not significantly so. In other words, the hypothesis of Martin, i.e. that competition from small firms limits the ability of the largest firms to exercise market power, is neither rejected nor supported.

\section{A critical level of small business presence}

We investigate whether the influence of small business share on price-cost margins differs between industries with a level of small business share below and above a critical level $L_{c}$ by introducing the multiplicative variables $D^{1} S B P$ and $D^{2} S B P$, respectively. Again we choose $L_{c}=0.50,0.55$, $0.60,0.65$ and 0.70 . The variable $D^{1}$ equals one if the average value of $S B P$ in an industry over the period 1974-1986 is lower than $L_{c}$ and equals zero otherwise. $D^{2}$ is defined as $1-D^{1}$ and thus $D^{2} S B P$ equals $S B P$ if the average $S B P$ is equal to or exceeds $L_{c}$, and equals zero otherwise.

Such a distinction is comparable with supposing that there is a critical four-firm seller concentration ratio. A number of studies have found support for such a critical concentration ratio. ${ }^{21}$ "Virtually all show a distinct upsurge in profit rates as the four-firm concentration ratio passes through a range somewhere between 45 and 59 percent. They lend support to Chamberlin's hypothesis that respect for mutual oligopolistic interdependence tends to coalesce at some critical level of seller concentration" (Scherer, 1980, p. 280). The connection between small business presence and concentration at the high end of the size-distribution can be illustrated as follows. A small business share below a certain level $L_{c}$ corresponds with a four-firm seller concentration ratio above $1-L_{c}$ $-R$, with $R$ defined as the share accounted for by the 'remaining' firms, i.e. firms not belonging to the largest four or to the small business.

So, based on the positive relation found between concentration and price-cost margins above a certain level of concentration, we expect to find a positive relation between small business presence and price-cost margins below a certain level of small business presence. In other words, we expect the variable $D^{1} S B P$ to influence the industry's price-cost margins positively and the variable $D^{2} S B P$ to leave the price-cost margins unaltered.

The results are in Table III. For all values of $L_{c}$, except $L_{c}=0.60$, the variables $D^{1} S B P$ and $D^{2} S B P$ appear to have no significant effect on price-cost margins. We will not pay further attention to the other coefficients. However, for $L_{c}=$ 0.60 we will discuss the results in more detail. The coefficients of all explanatory variables that were already introduced in equation (1) show minor differences when compared with the results of equation (1). The coefficients of the multiplicative variables $D^{1} S B P$ and $D^{2} S B P$ suggest that there is a critical level of $0.60^{22}$ in the small business presence. Price-cost margins are unaffected by the level of the small business share when the average 
TABLE III

Coefficients of the variables $D^{1} S B P$ and $D^{2} S B P$

\begin{tabular}{lll}
\hline$L_{c}$ & $D^{1} S B P$ & $D^{2} S B P$ \\
\hline 0.50 & $0.000(0.0)$ & $0.010(0.7)$ \\
0.55 & $0.019(0.9)$ & $0.015(1.1)$ \\
0.60 & $0.041(2.2)$ & $0.020(1.4)$ \\
0.65 & $0.027(1.6)$ & $0.016(1.2)$ \\
0.70 & $0.010(0.6)$ & $0.014(1.0)$ \\
\hline
\end{tabular}

small business share over the period 1974-1986 equals or exceeds 0.60 . A low level of small business presence has a positive significant effect on industry's price-cost margins. However, a formal statistical test on the equality of the estimated coefficients shows that the coefficients do not differ significantly from each other.

Drawing conclusions from these exercises we may say that if there is any effect of small business presence on price-cost margins it is a weak one: there is some evidence for a critical level of 0.60 in small business share.

The lack of empirical evidence of significant influences of small business presence on price-cost margins might be due to measurement problems. We chose for measurement in firms because measurement in employment can be biased by differences in labour productivity between small and large firms. Nevertheless we ran the aforementioned exercises with small business presence measured by the number of employees instead of firms. Still no significant effect of the small business share on price-cost margins is found.

Also, the definition of small can be argued upon. Firms employing less than 10 employees are not included. These firms account for more than 50 percent of the total number of firms and for about 8 percent of the total employment in Dutch manufacturing in 1984. This measurement problem is not as serious as it might seem at first sight because all other variables used in the empirical analyses are measured excluding the activities of the firms employing less than 10 employees. Furthermore, re-estimation of the model underlying equation (1) with small business share defined as the share of the number of firms accounted for by firms employing 1 to $50 \mathrm{em}$ - ployees yields regression results similar to those presented in equation (1).

Altogether, it appears that the above-mentioned measurement problems of the share of small business are not the source of the low correlations between small business presence and price-cost margins.

\section{Conclusion}

In this paper we investigated the influence of large firm dominance and small business presence next to that of the four-firm seller concentration ratio and some other market structure variables on Dutch manufacturing price-cost margins. We used a large data set consisting of 66 manufacturing industries from 1974 through 1986, covering 81 percent of total employment in Dutch manufacturing.

The empirical results provide us with the following conclusions. First, the presence of one or two dominant firms within an industry has a positive effect on industry's price-cost margins. Second, the presence of small business appears to have no significant influence on price-cost margins. Some evidence for a critical level of small business presence is found. In industries where small firms account for less than 60 percent of the number of firms price-cost margins are positively influenced by the small business share, whereas industry's price-cost margins are unaffected by this share if small firms account for 60 percent or more of the firms. In other words, price-cost margins of industries with a low small business share $(<0.60)$ are higher than those of industries with a high small business share $(\geqslant 0.60)$, ceteris paribus. Third, growth in the presence of small business does increase the level of competition which lowers industry's price-cost margins significantly. Fourth, the widely used four-firm seller concentration ratio does not have a significant effect on price-cost margins. This last result together with the one first mentioned suggests that large firm dominance does better reflect the market power to set prices about competitive levels than the four-firm seller concentration ratio. Furthermore, capital intensity, capacity utilization and sales growth affect price-cost margins positively, whereas competing imports affect them 
negatively. The influence of exports on price-cost margins depends on the extent to which buyers are concentrated.

The insignificant effect of the concentration ratio on price-cost margins confirms the feeling that a positive relationship between concentration and price-cost margins such as found in U.S. studies does not exist in some European open economies. ${ }^{23}$ However, it might be that such a relationship does exist but that it has remained unnoticed due to the quality of the data: at least four-digit data are required for a close correspondence with product markets and concentration ratios should be corrected for geographical dispersion of the product market. In most U.S. studies the data used meet these requirements.

The overall conclusion is that empirical investigations on the explanation of manufacturing price-cost margins may ignore the existence of a high small business presence but not that of large firm dominance or small business presence growth within an industry.

The empirical findings presented in this paper suggest the following policy implication. From a welfare point of view price-cost margins should be kept low. So, policy-makers should stimulate a continuous birth of small firms since a growth in the presence of small firms depresses the level of price-cost margins. Furthermore, the presence of one or two dominant firms within an industry leads to high price-cost margins so that the formation of dominant firms through mergers or takeovers in Dutch manufacturing industries should be restricted. However, the welfare disadvantage of these large internationals should first be weighed against their indispensable contribution to the Dutch economy as a whole.

Future research will focus on intra-industry differences between small (10 to 50 employees) and large (50 or more employees) Dutch manufacturing firms.

\section{Acknowledgements}

We gratefully acknowledge the financial support from the Netherlands Organization for Scientific Research (NWO). We thank Kees Bakker and Sjaak Vollebregt for collecting the data. Furthermore, we thank Aad Kleijweg, Sjaak Vollebregt and two anonymous referees for helpful comments on an earlier version of this paper. A previous version was read at the ECOZOEK-day, Rotterdam, June 3, 1992 and at the 19th EARIE-conference, Stuttgart, September 4-6, 1992.

\section{Notes}

1 In general, oligopoly theory points to higher prices in more concentrated industries. However, the conclusion of a critical examination by Demsetz (1974) reads: “. . theoretical support of the market concentration doctrine, including its barrier-to-entry variant, is weak or non-existent" (Demsetz, 1974 , p. 174). See for empirical surveys for example Weiss (1974) and more recently Weiss (1989). In Weiss (1974) a comprehensive table (Table 11, pp. 204-215) lists many empirical tests on the relationship between industrial concentration and profits and margins. Most studies show a significant positive effect of concentration on profits or margins, but there is also a number of studies that yield no significant effect on profits or margins. In Weiss (1989) results from studies on the concentration-price relation of separate industries (amongst others, cement, banking, airlines, supermarkets) are shown. In the concluding chapter of his book Weiss tries to give a general answer on the question "Does concentration raise price?". According to Weiss the results seem to yield overwhelming support for a positive relation between concentration and price. However, in Schmalensee (1989) a discussion of empirical studies on cross-section data led the author to Stylized Fact 4.5: "The relation, if any, between seller concentration and profitability is statistically weak, and the estimated concentration effect is usually small" (Schmalensee, 1989, p. 976).

2 Demsetz (1973) argues that the concentration-profitability relation reflects intra-industry efficiency differences rather than collusion. Studies aiming at distinguishing between the collusion hypothesis and the efficiency hypothesis find little support for either hypothesis but rather for their simultaneous working. See Ravenscraft (1983), Clarke, Davies and Waterson (1984), Schmalensee $(1985,1987)$ and Martin (1988). Some of these studies included both concentration and market share in explaining profitability to discriminate between both views. The results strongly support Schmalensee's Stylized Fact 4.11: “. . . the coefficient of concentration is generally negative or insignificant in regressions including market share" (Schmalensee, 1989, p. 984).

${ }^{3}$ However, some studies did investigate the influence of market shares of firms other than the top four. They focused on both four-firm seller concentration and marginal concentration, i.e. the market share accounted for by the fifththrough-eighth largest firms. Miller (1967) concluded that greater marginal concentration results in lower profitability, and the results of Collins and Preston (1969) suggest that this is only the case in industries having average concentration. Martin (1988) included the market share of all remaining firms too in explaining price-cost margins of groups of firms: 
the top four, the second four and the rest. Price-cost margins of the top four firms were found to be negatively influenced by marginal concentration. Unfortunately, influences on industry's price-cost margins were not considered.

4 For example, Ten Cate and Sprangers (1985) found a correlation coefficient of -0.95 between the four-firm concentration ratio (in employment) and the Theil-coefficient for Dutch manufacturing industries in the year 1981. A comparable value of correlation was found by Scherer and Ross (1990) between the four-firm concentration ratio (in sales) and the Herfindahl-Hirschman index for U.S. manufacturing in 1982.

5 See Bakker and Prince (1990) for a concise description of the Dutch manufacturing data set DUMA. This description and more details are available from the authors on request.

6 The Dutch industrial classification of firms (SBI) developed by the Netherlands Central Bureau of Statistics is used.

7 We made use of, among others, Dun's 15.000; The most important Dutch enterprises, Het Financieele Dagblad: De omzetciffers van 1984 and Bedrijfstakverkenning 1980, Deel 8: Chemische, rubber en kunststof verwerkende industrie.

8 Actually the numbers of so-called "activity units" were measured. An "activity unit" is a unit that is statistically measurable and has homogeneous economic activities. This implies that one firm, a part of a firm, or a few firms can be defined as an activity unit.

9 The correlation coefficient between small business presence measured in employment and that measured in firms is high: 0.83 .

10 That small firm presence varies considerably across manufacturing industries is also noticed in Acs and Audretsch (1989), where a model explaining the inter-industry variation in the presence of small firms in U.S. manufacturing is developed.

11 See Prince and Thurik (1992) for an extensive discussion and description of the model and the empirical results.

${ }_{12}$ In Dutch manufacturing the C4-ratio is only available in employment and unfortunately not in output as is often the case in other countries.

${ }^{13}$ See amongst others Khalilzadeh-Shirazi (1974) and Domowitz et al. (1986).

14 The choice of 10 year backwards is largely dictated by the data availability: before 1964 no investment figures are available. Thus the measure $\mathrm{K}$ ignores the amount of capital invested 11 or more years earlier, so that investments in plants and sites are probably underrated. Furthermore, $\mathrm{K}$ does not differentiate between types of investments and uses weighing schemes which are uniform over time. Alternative weighing schemes yield comparable results. Favourable properties of $\mathrm{K}$ are that it is (1) easily computable and (2) based on real investment figures instead of bookvalues (which avoids the endogeneity problem between accounting practices and profitability).

15 A Wharton index is computed by plotting time-series of average value-added. The straight line through the peaks is assumed to correspond to a capacity utilization of $100 \%$. The capacity utilization is defined as the ratio between the average value-added and the corresponding value of the straight line.
16 See for example, Khalilzadeh-Shirazi (1974), Pagoulatos and Sorenson (1976), and Pugel (1980).

17 In Prince and Thurik (1990) it is shown that exports do affect Dutch manufacturing price-cost margins positively for producer goods industries, but negatively for consumer goods industries.

18 Tests show that there is first-order autocorrelation and heteroskedasticity over the industries. The presented regression results are corrected for heteroskedasticity and autocorrelated errors by transforming the data. For all variables $X_{i t}$ (dependent and independent) the following transformation is applied.

$$
\begin{aligned}
\mathrm{X}_{i t}^{\mathrm{T}} & =\sqrt{\left(1-\hat{\rho}^{2}\right)} \mathrm{X}_{t t} / \hat{\sigma}_{i}, & & t=1 \\
& =\left(\mathrm{X}_{i t}-\hat{\rho} \mathrm{X}_{i t-1}\right) / \hat{\sigma}_{i}, & & t>1
\end{aligned}
$$

with $\hat{\rho}$ and $\hat{\sigma}_{i}, \hat{\mathrm{i}}=1, \ldots, \mathrm{n}$ obtained from the estimation of (a) and (b) respectively:

$$
\begin{aligned}
& \hat{\varepsilon}_{i t}=\rho \hat{\varepsilon}_{i t-1}+\varphi_{i t} \text {, where } \hat{\varepsilon}_{i t} \text { are the estimated residuals } \\
& \text { of equation (1) before transformation; } \\
& \hat{\eta}_{i t}^{2}=\sigma_{i}^{2} D_{i t}+v_{i t} \text {, where } \hat{\eta}_{i t}=\sqrt{\left(1-\hat{\rho}^{2}\right)} \hat{\varepsilon}_{i t}, \quad t=1 \\
& =\hat{\varepsilon}_{i t}-\hat{\rho} \hat{\varepsilon}_{i t-1}, \quad t>1 \\
& D_{i t}=1 \text { for industry i } \\
& =0 \text { otherwise. }
\end{aligned}
$$

See for example Kennedy (1979, p. 98-102) and Den Hertog, Kloek and Thurik (1991) for some insights in how to deal with problems like heteroskedasticity and autocorrelation in similar situations. Industry-dummies were not included because the above-mentioned method already accounts for cross-section effects. Furthermore, it is known that the inclusion of industry-dummies produces fixed-effects estimates, which have to be associated rather with year-to-year changes than with long-run influences. The investigation of short-run effects is not the purpose of the present paper. See Prince and Thurik (1992) for an alternative solution: the socalled 'within-between' method.

19 In this paper the $5 \%$ level of significance is used.

20 See Chow (1983), p. 60 and 61 for the precise test.

21 See for example the pioneering study by Bain (1951), the studies by White (1976), Dalton and Penn (1976), and two out of three cases described in Weiss (1991).

${ }^{22}$ For the industries in which the average small business share is lower than 0.60 the corresponding average four-firm concentration ratio takes the value 0.52 (note that the small business share is measured in firms and the four-firm seller concentration ratio in employment).

23 See for example Jacquemin et al. (1980) for Belgium and Clarke (1985, p. 112-113) for a discussion of U.K. studies.

\section{References}

Acs, Zoltan J. and David B. Audretsch, 1989, 'Entrepreneurial Strategy and the Presence of Small Firms', Small Business Economics 1, 193-213. 
Bain, J. S., 1951, 'Relation of Profit Rate to Industry Concentration: American Manufacturing, 1936-1940', Quarterly Journal of Economics 65, 293-324.

Bakker, K. and Y. M. Prince, 1990, 'Data Set of Dutch Manufacturing per Three-Digit Industry, 1974-1986', mimeograph, Department of Fundamental Research, Research Institute for Small and Medium-Sized Business, Zoetermeer, The Netherlands.

Baldwin, J. R. and P. K. Gorecki, 1990, Measures of Market Structure and the Intensity of Competition', paper presented at the XVII-th EARIE-Conference Lisbon 1990.

Bedrijfstakverkenning 1980, Deel 8: Chemische, rubber- en kunststofverwerkende industrie, Ministerie van Economische Zaken, 's-Gravenhage: Staatsuitgeverij.

Brooks, D, 1973, Market Structure and Seller Profitability, San Diego: University Press San Diego State University.

Chow, G. C., 1983, Econometrics, New York: McGrawHill.

Clarke, Roger, Stephen Davies and Michael Waterson, 1984, 'The Profitability-Concentration Relation: Market Power or Efficiency?', Journal of Industrial Economics 32, 435450.

Collins, N. R. and L. E. Preston, 1969, 'Price-Cost Margins and Industry Structure', Review of Economics and Statistics 51, 271-286.

Dalton, J. A. and J. W. Penn, 1976, 'The ConcentrationProfitability Relationship: Is There a Critical Concentration Ratio?', Journal of Industrial Economics 25, 133142.

Demsetz, Harold, 1973, The Market Concentration Doctrine, Palo Alto: AIE-Hoover Policy Studies.

Demsetz, Harold, 1974, 'Two Systems of Belief about Monopoly', in H. J. Goldschmid, H. M. Mann and J. F. Weston (eds.), Industrial Concentration: The New Leaming, Boston: Little, Brown and Company, pp. 164-184.

Den Hertog, R. G. J., T. Kloek and A. R. Thurik, 1991, 'Industrial Econometrics and Panel Data: A Full Costs Model of Retail Margins', Report 9147/A, Econometric Institute, Erasmus University Rotterdam, Rotterdam, The Netherlands.

Domowitz, I., R. G. Hubbard and B. C. Petersen, 1986, 'Business Cycles and The Relationship Between Concentration and Price-Cost Margins', Rand Journal of Economics 17, 1-17.

Dun, 1989, Dun's 15.000; The Most Important Dutch Enterprises 1990 (in Dutch: Dun's 15.000; De belangrijkste Nederlandse ondernemingen 1990), Rotterdam: Dun \& Bradstreet International.

Het Financieele Dagblad, 1985, De omzetcijfers van 1984, nr. 230.

Kennedy, Peter, 1979, A Guide to Econometrics, Oxford: Basil Blackwell.

Khalilzadeh-Shirazi, J., 1974, 'Market Structure and PriceCost Margins in United-Kingdom Manufacturing Industries', Review of Economics and Statistics 56, 67-76.

Kwoka, J. E., Jr., 1979, 'The Effect of Market Share Distribution on Industry Performance', Review of Economics and Statistics 61, 101-109.
Kwoka, J. E., Jr., 1981, 'Does the Choice of Concentration Measure Really Matter?', Journal of Industrial Economics 29, 445-453.

Lustgarten, S. H., 1975, 'The Impact of Buyer Concentration in Manufacturing Industries', Review of Economics and Statistics 57, 125-132.

Martin, Stephen, 1988, Industrial Economics, New York: Macmillan Publishing Company.

Martin, Stephen, 1988, 'Market Power and/or Efficiency?', Review of Economics and Statistics 70, 331-335.

Miller, R. A., 1967, 'Marginal Concentration Ratios and Industrial Profit Rates', Southern Economic Journal 34, 259-267.

Pagoulatos, E. and R. Sorensen, 1976, 'Foreign Trade, Concentration and Profitability in Open Economies', European Economic Review 8, 255-267.

Prince, Y. M. and A. R. Thurik, 1990, 'Concentration and Cyclical Behaviour of Price-Cost Margins in Dutch Manufacturing', Research paper 90.01, Department of Fundamental Research, Research Institute for Small and Medium-Sized Business, Zoetermeer, The Netherlands.

Prince, Y. M. and A. R. Thurik, 1992, 'Price-Cost Margins in Dutch Manufacturing: Effects of Concentration, Business Cycle and International Trade', De Economist 140.

Ravenscraft, David J., 1983, 'Structure-Profit Relationships at the Line of Business and Industry Level', Review of Economics and Statistics 65, 22-31.

Scherer, F. M., 1980, Industrial Market Structure and Economic Performance, Chicago: Rand Mcnally.

Scherer, F. M. and David Ross, 1990, Industrial Market Structure and Economic Performance, Boston: Houghton Mifflin Company.

Schmalensee, Richard, 1985, 'Do Markets Differ Much?', American Economic Review 75, 341-351.

Schmalensee, Richard, 1987, 'Collusion Versus Differential Efficiency: Testing Alternative Hypotheses', Journal of Industrial Economics 35, 399-425.

Schmalensee, Richard, 1989, 'Inter-Industry Studies of Structure and Performance', in R. Schmalensee and R. D. Willig (eds.), Handbook of Industrial Organization, vol. II, Amsterdam: Elsevier Science Publishers, pp. 9521009.

Schumacher, Ute, 1991, 'Buyer Structure and Seller Performance in U.S. Manufacturing Industries', Review of Economics and Statistics 73, 277-284.

Smidt, M. de and E. Wever, 1987, The Dutch Manufacturing Industry: Position, Dispersion and Structure (in Dutch: De Nederlandse industrie: positie, spreiding en struktuur), Assen: Van Gorcum \& Comp.

Storey, D. J., 1989, 'Firm Performance and Size: Explanations from the Small Firm Sectors', Small Business Economics 1, 175-180.

Ten Cate, A. and A. H. Sprangers, 1985, 'Concentration and Deconcentration in Manufacturing Industries (1976 and 1981)', Statistisch Magazine (CBS) 5, 12-20.

Weiss, Leonard W., 1974, 'The Concentration-Profits Relationship and Antitrust', in H. J. Goldschmid, H. M. Mann and J. F. Weston (eds.), Industrial Concentration: The New 
Learning, Boston: Little, Brown and Company, pp. 184233.

Weiss, Leonard W. (ed.), 1989, Concentration and Price, Cambridge: MIT Press.

Weiss, Leonard W., 1991, 'Concentration, Price, and Critical Concentration Ratios', in David B. Audretsch and Hideki
Yamawaki (eds.), Structure, Conduct and Performance, New York: New York University Press, pp. 351-365.

White, L. J., 1976, 'Searching for the Critical Concentration Ratio: An Application of the Switching Regimes' Technique', in S. M. Goldfeld and R. E. Quandt (eds.), Studies in Nonlinear Estimation, Cambridge: Ballinger, pp. 6175. 